„Bohemistyka” 2020, nr 2, ISSN 1642-9893

Lenka PTAK

DOI: $10.14746 /$ bo.2020.2.1

Wrocław

\section{Sandhi na granicy międzywyrazowej. Badanie sondażowe w czeskim korpusie języka mówionego Ortofon}

Keywords: modern Czech language, sandhi, corpus of spoken language, phonetic research

Słowa kluczowe: współczesny język czeski, sandhi, korpus języka mówionego, badania fonetyczne

\section{Abstract}

The object of the investigation is sandhi in the modern Czech language based on phonetic research of Czech corpus of spoken language - ORTOFON. In the Czech Standard norm word-final obstruents undergo devoicing before initial sonant of the following word. The research showed that the standard norm does not reflect fully the modern language situation. In the modern Czech language the word-final obstruents may undergo voicing before initial sonant. The frequency of voiced word-final obstruents before initial sonant in analyzed material was very high.

Przedmiotem niniejszego artykułu jest sandhi w języku czeskim, analiza zjawiska oparta na materiale wyekscerpowanym z czeskiego korpusu języka mówionego ORTOFON. Norma literackiego języka czeskiego na granicy międzywyrazowej dopuszcza wyłącznie realizację bezdźwięcznego wygłosowego obstruentu przed nagłosowym sonantem. Przeprowadzone badania pokazują, że w języku czeskim dochodzi do częstych odstępstw od istniejącej normy literackiej. Na granicy międzywyrazowej rejestruje się wymówienia $\mathrm{z}$ udźwięczniającą spółgłoską w wygłosie przed nagłosowym sonantem. Odstępstwo od normy jest bardzo wysokie.

Jednym z celów badań nad współczesnym językiem czeskim jest systematyczna weryfikacja starszych badań i tradycyjnych wyobrażeń o języku na materiale współczesnego języka mówionego za pomoca środków, które nam zapewniają dzisiejsze możliwości technologiczne. Analiza danych pochodzących z czeskiego korpusu języka mówionego jest jednym ze sposobów pozyskiwania informacji o sytuacji językowej współczesnej czeszczyzny, dla której charakterystyczny jest rozdźwięk między normą języka literackiego a uzusem. Podejście korpusowe w analizie danych językowych uważane jest obecnie za jedna z reprezentatywnych metod a wyniki akceptowane są jako ważne i wiarygodne. Korpusy zapewniają dane, które powinny stanowić przykłady naturalnej komunikacji między ludźmi w różnych formach. Dostarczają danych empirycznych, co pozwala nam przyjąć, że mamy doczynienia z metodologią obiektywną (Čermák 1995; Cvrček, Kováríková 2011). W niniejszym artykule analizie zostaną poddane wybrane zjawiska fonetyczne dotyczące upodobnień na granicy między wyrazami - sandhi międzywyrazowe z wykorzystaniem materiału językowego wyekscerpowanego z czeskiego korpusu języka mówionego ORTOFON.

\section{Sandhi na granicy międzywyrazowej. Połączenia obstruent + sonant}

W literaturze przedmiotu trudno znaleźć precyzyjną definicję sandhi. Za Ireną Sawicką przyjmujemy, że są to alternacje dźwięcznych i bezdźwięcznych obstruentów na granicach morfologicznych uwarunkowane kontekstem fonologicznym i/lub fonetycznym, czy też dystrybucja dźwięcznych i bezdźwięcznych obstruentów na granicach jednostek morfologicznych uwarunkowana kontekstem fonologicznym i/lub fonetycznym (Sawicka 2013, s. 15).

Co się tyczy sandhi na granicy międzywyrazowej, wśród języków słowiańskich przeważa fonetyka ubezdźwięczniająca. I. Sawicka zwraca uwagę na niejednolitość w realizacji upodobnień międzywyrazowych na terenie słowiańskim i wyróżnia dwa obszary, wyraźnie wyodrębnione i niejednolite, w których występuje inny rodzaj fonetyki międzywyrazowej. Jak pisze Sawicka, dla części północnej charakterystyczna jest fonetyka udźwięczniająca, natomiast w południowo-zachodniej występują liczne ograniczenia upodobnień (Sawicka 
2007, s. 175). W naszej pracy przyjrzymy się bliżej regularności sandhi na granicy międzywyrazowej w języku czeskim.

We współczesnym języku czeskim rejestrujemy kilka odmian języka narodowego. Grażyna Balowska na podstawie szczegółowych opracowań dyferencjacji języka czeskiego tworzy model odpowiadający stratyfikacji języka polskiego. Podział Balowskiej wygląda następująco:

- czeski język oficjalny (literacki), „spisovná čeština”, który występuje w dwu wariantach: a) pisany język oficjalny (literacki): ,psaná čeština”, „knižní čeština”; b) potoczny język oficjalny (literacki): „hovorová čeština”;

- w opozycji do oficjalnej odmiany języka czeskiego stoją - z jednej strony - jezyk czeski potoczny nieoficjalny (nieliteracki) „obecná čeština”, a z drugiej odmiany terytorialne, obejmujące interdialekty i dialekty (Balowska 2006, s. 26).

Wewnętrzne zróżnicowanie narodowego języka czeskiego ma znaczący wpływ również na płaszczyznę dźwiękową języka. Zgodnie z normą literacką języka czeskiego na granicy wyrazowej połączenie bez pauzy jednorodnych obstruentów nie wywołuje żadnych zmian fonetycznych, jak np. w typ pisma [tip pi:sma], koráb doplul [kora:b doplul]. W przypadku grup różnorodnych pod względem dźwięczności dochodzi do neutralizacji tej opozycji, podobnie jak wewnątrz wyrazów, np. klub přátel [klup prạa:tel], výstup dvojice [vi:stub dvojice]. Inaczej przedstawiają się połączenia obstruentów dźwięcznych i bezdźwięcznych w wygłosie pierwszego wyrazu przed nagłosowym sonantem - /1/, /r/, /m/, /n/, /̌n/, /j/, gdzie norma czeskiego języka literackiego dopuszcza na granicy międzywyrazowej wyłącznie bezdźwięczną realizację, np. had leze [hat leze], pohyb rukou [pohıp rukou], kus masa [kus masa], léčit nemoci [le:t]It nemotsı], důvod ničeni [du:vod nIt̂eni:], útok jednotki [u:tok jednotkI] (por. Palková 2013, s. 94; Krčmová 2008, s. 184-185).

Jednakże w dialektach środkowomorawskich, wschodniomorawskich czy śląskich wystepuje realizacja dźwięcznego obstruentu $\mathrm{w}$ wygłosie pierwszego wyrazu na granicy międzywyrazowej przed samogłoską lub sonantem, np. w dialekcie środkowomorawskim - tak jo, [tag jo], s autem [z autem]; w dialekcie wschodniomorawskim -

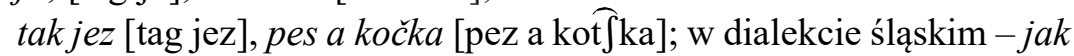
mu je [jag mu je] (Bogoczová 2012, s. 74, 84, 95).

Włodzimierz Pianka ze względu na typ fonetyki międzywyrazowej dzieli słowiańszczyznę na dwie części, zwracając uwagę również na odmienność w realizacji sandhi międzywyrazowego na obszarze Czech właściwych i Moraw: 1. obszar z obowiązującą fonetyką udźwięczniającą - język ukraiński, słowacki, morawska odmiana języka czeskiego oraz południowo-zachodni wariant polszczyzny; 2. obszar z obowiązującą fonetyką ubezdźwięczniającą - języki południowosłowiańskie, białoruski, rosyjski, górnołużycki, język czeski oraz północno-wschodni wariant polskiego (Pianka 2000, s. 105).

\section{Analiza materiału. Realizacja połączeń obstruent bezdźwięczny/dźwięczny + sonant}

Ta część artykułu koncentruje się na analizie dwóch grup połączeń na granicy międzywyrazowej. Jedna z nich to grupa połączeń obstruentów bezdźwięcznych/dźwięcznych + sonant $l$, a druga to połączenia »obstruent bezdźwięczny $c+$ poszczególne sonanty nagłosowe«.

Analizowany przez nas materiał jest bardzo różnorodny zarówno pod względem tematu, jak i zwartości a w całości został wyekscerpowany z czeskiego korpusu języka mówionego ORTOFON. Korpus ORTOFON, który powstawał w latach 2012-2017, zawiera 332 nagrania oraz 1014786 słów pochodzących od 624 różnych mówców. W trakcie gromadzenia danych autorzy zadbali o to, aby korpus był zrównoważony pod względem czterech podstawowych kategorii socjolingwistycznych: płci, wieku, wykształcenia i rejonu zamieszkania w dzieciństwie (do 15 roku życia). Chociaż pierwotnym przeznaczeniem korpusu ORTOFON nie są badania dialektologiczne lub fonetyczne, uproszczona transkrypcja fonetyczna pozwala na weryfikację wymowy (wariantów artykulacyjnych czy regionalnych). Korpus ten 
jest cennym źródłem realnych danych, które można z powodzeniem wykorzystać do analiz fonetycznych.

Transkrypcja języka mówionego w korpusie ORTOFON realizowana jest na dwóch poziomach: ortograficznym i fonetycznym. Płaszczyzna ortograficzna służy przede wszystkim do zrozumienia zapisanej konwersacji i orientacji w niej, podczas gdy płaszczyzna fonetyczna przechwytuje rzeczywistą realizację mowy przez zmodyfikowaną transkrypcję fonetyczną. Owym płaszczyzną towarzyszy jeszcze metajęzykowa, która wychwytuje dźwięki towarzyszące wytwarzane mówcami, np. kaszel, śmiech albo dźwieki pochodzace $z$ bezpośredniego otoczenia, które mogą wpłynąć na rozmowę, np. dzwonek telefonu, który przerywa rozmowę. W odróżnieniu od serii ORAL korpus ORTOFON jest lematyzowany i tagowany, co umożliwia szerszy zakres prowadzonych badań (o korpusie języka mówionego ORTOFON zob. http://wiki.korpus.cz/doku.php/cnk:ortofon).

Z materiału korpusowego korzystając z zapytania CQL, które wyszukuje wyników za pomocą języka zapytań z dokładnie zdefiniowaną syntaksą, wyodrębniono 870 połączeń typu obstruent bezdźwięczny/dźwięczny + sonant $l$ na granicy międzywyrazowej. Aby wyszukać odpowiednie połączenia międzywyrazowe, wykorzystano następujące zapytania:

[word=".*t"][word="l.*"];

[word=".*d" \& pos="N"][word="l.*"];

[word=".*c" | word=".*dz"][word="l.*"]

[word=".*s"] [word="l.*"];

[word $=" . *$ ž"] $[$ word $=" 1 . * "]$;

[word=".+s" | word=".+z"][word="l.*"];

[word $=" . * \mathrm{c}^{\prime \prime} \mid$ word=".*dž"][word="1.*"];

[word $=" .+\mathrm{k}^{\prime \prime} \mid$ word $\left.=" .+\mathrm{g} "\right][$ word $=" 1 . * "]$;

[word $="$ "*ch"][word="1.*"];

$[$ word $=" .+[\wedge \mathrm{c}] \mathrm{h} "][$ word $=" 1 . * "]$.

Niektóre zapytania zostały utworzone tak, aby pominięto połączenia na granicy z przyimkiem jednosylabowym, gdzie norma języka czeskiego dopuszcza realizację dźwięcznego obstruentu w wygłosie przyimka przed nagłosowym sonantem, np. nad lesem [nad lesem].
Dane pozyskane w ten sposób zostały poddane kolejnemu posortowaniu (np. weryfikacji poprawności otrzymanych poświadczeń, selekcji według rejonu zamieszkania w dzieciństwie) a charakterystykę omawianych połączeń przedstawia tabela 1 .

Tabela 1. Wygłosowe obstruenty bezdźwięczne/dźwięczne przed nagłosowym sonantem na granicy międzywyrazowej

\begin{tabular}{|c|c|c|c|c|c|}
\hline \multirow{2}{*}{$\begin{array}{l}\text { Wygłos } \\
\text { pierwszego } \\
\text { wyrazu }\end{array}$} & \multirow{2}{*}{$\begin{array}{c}\text { Nagłos } \\
\text { drugiego } \\
\text { wyrazu }\end{array}$} & \multicolumn{4}{|c|}{ Liczba połączeń } \\
\hline & & ogółem & $\begin{array}{c}\text { realizacja } \\
\text { bezdźwięcz- } \\
\text { na }\end{array}$ & $\begin{array}{l}\text { realizacja } \\
\text { dźwięczna }\end{array}$ & $\begin{array}{l}\text { inne } \\
\text { realizacje }\end{array}$ \\
\hline$t$ & \multirow{9}{*}{$\mathrm{L}$} & 394 & 186 & 120 & 88 \\
\hline$d$ & & 2 & 1 & 1 & 0 \\
\hline$s$ & & 15 & 13 & 2 & 0 \\
\hline$k$ & & 149 & 83 & 66 & 0 \\
\hline ch & & 149 & 82 & {$[\gamma] 37$} & $\begin{array}{c}4 \\
{[\text { [ ] } 26} \\
\end{array}$ \\
\hline$\check{s}$ & & 40 & 32 & 8 & 0 \\
\hline$\check{z}$ & & 27 & 13 & 14 & 0 \\
\hline$c$ & & 93 & 68 & 11 & 14 \\
\hline$\check{c}$ & & 1 & 1 & 0 & 0 \\
\hline \multicolumn{2}{|c|}{ Łącznie } & 870 & 479 & 259 & 132 \\
\hline
\end{tabular}

Jak już wspomnieliśmy w materiale wystąpiło 870 połączeń typu obstruent bezdźwięczny/dźwięczny + sonant $l$ na granicy międzywyrazowej. Wszystkie czeskie obstruenty wchodzą w opozycję dźwięczności. System odnotowuje 7 par fonemów a cztery pary w dystrybucji komplementarnej: /p/ - /b/, /t/ - /d/, /c/ - / / /, /k/ - /g/,/f/ - /v/,/s/ - /z/, $/ \mathrm{s} /-/ \mathrm{z} /, / \mathrm{x} /-/ \mathrm{h} /, / \widehat{\mathrm{ts}} /-/ \mathrm{d} \mathrm{z} /, / \overparen{\mathrm{t} J} /-/ \widehat{\mathrm{d}} \mathrm{z} /, / \mathrm{r} /-/ \mathrm{r} /$. Frekwencja poszczególnych spółgłosek właściwych w omawianej pozycji była bardzo zróżnicowana. W wygłosie pierwszego wyrazu najczęściej pojawiało się $t$. Frekwencja występowania tego segmentu w materiale korpusowym wynosi $45 \%$ wszystkich przykładów tego typu. Najrzadszym obstruentem w pozycji wygłosowej pierwszego wyrazu było $\check{c}(0,1 \%)$ oraz $d$ $(0,2 \%)$. W materiale nie odnotowano żadnych połączeń typu obstruent dźwięczny $z / g / h / d z / d z ̌+$ sonant $l$. Niska częstość występowania 
niektórych segmentów w wygłosie wyrazu jest naturalna. Korpus narodowy języka czeskiego (KonText - syn2015) podaje zaledwie 9 poświadczeń z obstruentem $d \check{z}$ w omawianej pozycji, 0 przykładów z obstruentem $d z$ w omawianej pozycji i 100 poświadczeń z obstruentem $g$ w omawianej pozycji.

Sposób realizacji wygłosowych obstruentów przed nagłosowym sonantem na granicy międzywyrazowej w badanym materiale nie zawsze był zgodny z normą literacką języka czeskiego. W wymowie mówców przeważała bezdźwięczna realizacja wygłosowych obstruentów (55\% wszystkich wymówień), np. padesát let [padesa:t let], čas letí [ $\widehat{\mathrm{t} \int a s}$ leci:], mladých lidí [mladi:x liłi:], dostatek lidí [dostatek 1ıji:], metodických listů [metodıtski:x 1Istu:], jednakże realizacja dźwięczna wygłosowego obstruentu stanowi aż 30\% wszystkich wymówień, np. kupovat lyže [kupovad 1ıze], dvacet lidi [dvatsed 1ıji:],

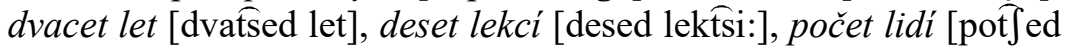
Iıłi:], několik let [nekolıg let], víc lidí [vi:đ̂d lıłi:], kus lesa [kuz lesa],

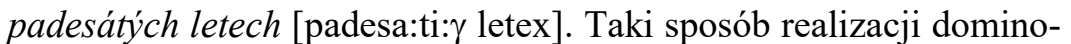
wał w wypowiedziach mówców z rejonu Moraw i Śląska. Wypowiedzi osób pochodzących z Moraw i Śląska stanowiły:

- 53\% wymówień wyekscerpowanego materiału w połączeniach obstruent bezdźwięczny $t+$ sonant $l \mathrm{z}$ czego $45 \%$ stanowią realizacje dźwięczne [d];

- 46\% wymówień wyekscerpowanego materiału w połączeniach obstruent bezdźwięczny $s+$ sonant $l$ z czego $1 \%$ stanowią realizacje dźwięczne [z];

- 60\% wymówień wyekscerpowanego materiału w połączeniach obstruent bezdźwięczny $k+$ sonant $l$ z czego $60 \%$ stanowią realizacje dźwięczne [g];

- 48\% wymówień wyekscerpowanego materiału w połączeniach obstruent bezdźwięczny ch + sonant $l \mathrm{z}$ czego $37 \%$ stanowią realizacje dźwięczne $[\gamma]$;

- 37\% wymówień wyekscerpowanego materiału w połączeniach obstruent bezdźwięczny $\check{s}+$ sonant $l$ z czego $27 \%$ stanowią realizacje dźwięczne [3];
- 37\% wymówień wyekscerpowanego materiału w połączeniach obstruent dźwięczny $\check{z}+$ sonant $l \mathrm{z}$ czego $80 \%$ stanowią realizacje dźwięczne [3];

- 50\% wymówień wyekscerpowanego materiału w połączeniach obstruent bezdźwięczny $c+$ sonant $l \mathrm{z}$ czego $21 \%$ stanowią realizacje dźwięczne $[\widehat{\mathrm{dz}}]$;

- 100\% wymówień wyekscerpowanego materiału w połaczeniach obstruent bezdźwięczny $\check{c}+$ sonant $l$ z czego $0 \%$ stanowią realizacje

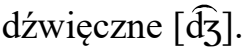

W wymówieniach osób pochodzących z Czech właściwych zdecydowanie przeważały realizacje zgodne z normą literacką, czyli bezdźwięczna realizacja obstruentu wygłosowego (93\% wymówień). Porównując frekwencję dźwięcznych realizacji obstruentu wygłosowego, można zauważyć, że najczęściej proces ten zachodził w realizacji wygłosowego $k$ przed nagłosowym sonantem $l$ (12 przykładów wymówień), np. tolik lidí [tolıg lıłi:], kolik lidí [kolıg 1ıłi:], viol jak lep [vu:1 jag lep], já tě tak lituju [ja: ce tag lituju], nějak loni [nejag lojı]. Zdecydowanie najrzadziej na granicy międzywyrazowej przed nagłosowym sonantem drugiego wyrazu udźwięcznieniu ulegało wygłosowe $t$ (0 przykładów wymówień).

$\mathrm{W}$ analizowanym materiale zaobserwowano zamiast spodziewanej bezdźwięcznej lub wychodzącej poza normę dźwięcznej realizacji wygłosowych obstruentów przed nagłosowym $l$ również inne realizacje, których powstanie może tkwić w niedokładnej, szybkiej wymowie, ale też w nieznajomości współczesnej czeskiej normy ortoepicznej. Wyodrębniono 131 takich wymówień. Najwięcej przykładów dotyczyło realizacji $t$ oraz ch przed nagłosowym sonantem $l$, np. brak realizacji $t \mathrm{w}$ wygłosie čtrnáct let [ [t trna: Ts let], dvacet let [dvatse let],

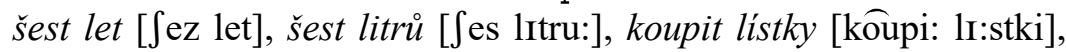
dělat lumpárny [łela lumpa:rni], dost lidi [do:s lıłi:], fakt líbi [fag li:bi:], oraz realizacja [ $\mathrm{h}]$ w połączeniach »bezdźwięczny obstruent $c h$ + sonant $l \ll$, np. těch lidí [ceh liłi:], těch lesů [ceh lesu:], ve kterých ležely [ve kteri:h lezelI], nějakých lahví [na:kih lahvi:], třech letech 
[troef letex]. Takie realizacje odnotowaliśmy zarówno u mówców pocho- dzących z Moraw, Śląska, jak i również z Czech właściwych.

Zaobserwowane w badanym materiale dźwięczne realizacje wygłosowego obstruentu przed nagłosowym sonantem ze względu na częstość występowania trudno uznać za przypadkowe. Wyniki badań udowodniły, że sposób realizacji pewnych kontekstów ma związek $\mathrm{z}$ rejonem zamieszkania informatora.

Druga analizowana grupa połączeń międzywyrazowych to grupa obstruent bezdźwięczny $c+$ sonant. Łącznie w materiale wyekscerpowano 2471 połączenia. W pozycji nagłosowej w analizowanych przykładach wystąpiło 6 sonantów - $/ l /,|r /, / m /|, n /, / \check{n} /, / j /$.

Aby wyszukać odpowiednie połączenia międzywyrazowe, wykorzystano następujące zapytania:

[word=".*c"][word="1.*"];

[word $\left.=" . *{ }^{*} "\right][$ word $=" \mathrm{r} . * "] ;$

[word $\left.=" . * c^{\prime \prime}\right][$ word $=" m . * "]$;

[word=".*c"][word="n[^ěi].*"];

[word=".*c"][word="ni.*"|word="ně.*"];

[word=".*c"][word="j[^s].*"]

Podobnie jak w poprzedniej analizie materiału dane pozyskane w ten sposób zostały poddane kolejnemu posortowaniu (np. weryfikacji poprawności otrzymanych poświadczeń, selekcji według rejonu zamieszkania w dzieciństwie).

Zapytanie CQL dla połączenia obstruent bezdźwięczny $c+\operatorname{sonant} j$ utworzono tak, aby pominąc połączenia obstruent bezdźwięczny $c+$ formy czasownika být - jsem, jsi, jsme, jste (z brakiem realizacji nagłosowego $j \rightarrow$ [sem], [sI], [sme], [ste]).

Spośród wybranych przykładów z kontekstem obstruent bezdźwięczny $c+$ sonant na granicy międzywyrazowej najliczniejsze były grupy $c+n$. Ich frekwencja wynosiła około $61 \%$ wszystkich połączeń w omawianej pozycji. Do względnie częstych można także zaliczyć inne połączenia z wygłosowym $c$ pierwszego wyrazu: $c+j, c$ $+m$. Co prawda, częstość występowania wymienionych grup osiagała niższe wartości (dla $c+j-20 \%$, dla $c+m-8 \%$ ), ale w porównianiu z pozostałymi połączeniami obstruentu bezdźwięcznego $c$ z sonantem na granicy międzywyrazowej i tak była wysoka. Dla niektórych kontekstów w materiale korpusowym wystąpiły nieliczne przykłady, np. dla połączenia $c+r$ odnotowano 36 wymówień $(1,5 \%)$ a dla $c+l$ odnotowano 93 połączenia $(3,7 \%)$. Szczegółową charakterystykę połączeń obstruent bezdźwięczny $c+$ poszczególne sonanty nagłosowe przedstawia tabela 2 .

Tabela 2. Połączenia obstruent bezdźwięczny $c+$ poszczególne sonanty nagłosowe na granicy międzywyrazowej

\begin{tabular}{|c|c|c|c|c|c|}
\hline \multirow[b]{2}{*}{$\begin{array}{c}\text { Wygłos } \\
\text { pierwszego } \\
\text { wyrazu }\end{array}$} & \multirow[b]{2}{*}{$\begin{array}{c}\text { Nagłos } \\
\text { drugiego } \\
\text { wyrazu }\end{array}$} & \multicolumn{4}{|c|}{ Liczba połączeń } \\
\hline & & ogółem & $\begin{array}{l}\text { Realizacja } \\
\text { bezdźwięcz- } \\
\text { na [ts] }\end{array}$ & $\begin{array}{c}\text { realizacja } \\
\text { dźwięczna } \\
\text { [d̄ }]\end{array}$ & $\begin{array}{l}\text { inne } \\
\text { realizacje }\end{array}$ \\
\hline \multirow{18}{*}{$\mathrm{C}$} & \multirow{3}{*}{$l$} & 93 & 68 & 11 & 14 \\
\hline & & M 47 & M 28 & M 10 & M9 \\
\hline & & Č 46 & Č 40 & Č 1 & Č 5 \\
\hline & \multirow{3}{*}{$r$} & 36 & 25 & 7 & 4 \\
\hline & & M 14 & M 7 & M 4 & M 3 \\
\hline & & Č 22 & Č 18 & $\check{C} 3$ & $\check{C} 1$ \\
\hline & \multirow{3}{*}{$m$} & 197 & 142 & 33 & 22 \\
\hline & & M 89 & M 53 & M 24 & M 12 \\
\hline & & Č 108 & Č 89 & Č 9 & Č 10 \\
\hline & \multirow{3}{*}{$n$} & 1515 & 871 & 274 & 370 \\
\hline & & M 726 & M 321 & M 179 & M 226 \\
\hline & & Č 789 & $\check{C} 550$ & Č 95 & Č 144 \\
\hline & \multirow{3}{*}{$\check{n}$} & 122 & 78 & 18 & 26 \\
\hline & & M 62 & M 33 & M 13 & M 16 \\
\hline & & Č 60 & Č 45 & C 5 & Č 10 \\
\hline & \multirow{3}{*}{$j$} & 508 & 384 & 94 & 30 \\
\hline & & M 261 & M 162 & M 77 & M 22 \\
\hline & & Č 247 & Č 222 & Č 17 & Č 8 \\
\hline \multirow{3}{*}{\multicolumn{2}{|c|}{ Łącznie }} & 2471 & 1568 & 437 & 466 \\
\hline & & $\mathrm{M}$ & M 622 & M 307 & M 288 \\
\hline & & $\check{\mathrm{C}}$ & С̆ 946 & Č 130 & С̆ 178 \\
\hline
\end{tabular}

${ }^{1}$ W tabeli wykorzystano skróty M i Č odpowiednio dla mówców pochodzących z Moraw/Śląska oraz Czech właściwych. 
Jeśli chodzi o sposób realizacji połączeń obstruent bezdźwięczny $c$ + poszczególne sonanty nagłosowe na granicy międzywyrazowej, to w wymowie mówców dominował typ zgodny z normą literacką języka czeskiego (63\% wszystkich połączeń), np. vủbec nic [vu:bets nIts], nic moc [nIts mots], tisic mužů [cisi:ts muzu:], moc rád [mots rát], víc lidi [vi:ts liłi:], noc nespala [nots nespala]. Jak wynika z tabeli 2, taki sposób realizacji przeważał u mówców pochodzących z Czech właściwych (60\% realizacji bezdźwięcznej wygłosowego obstruentu $c[\widehat{\mathrm{tS}}])$.

Realizacja wychodząca poza normę języka czeskiego, czyli realizacja dźwięczna wygłosowego obstruentu $c$ [ब]d] stanowi około $17 \%$ wszystkich wymówień, np. vưbec nic [vu:bedz nIts], nic moc [nI $\widehat{d z}$

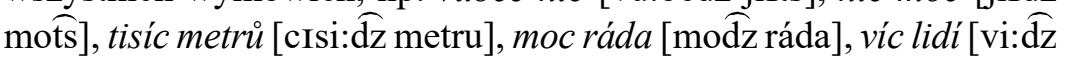
1ıłi:], nakonec jako [nakone đz jako]. Taki sposób realizacji obstruentu $c$ przed poszczególnymi sonantami nagłosowymi wyraźnie domino-

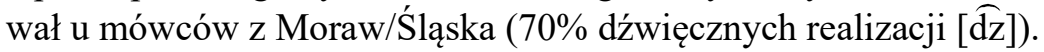

W analizowanym materiale korpusowym zaobserwowano wysoką frekwencję realizacji innych niż tych zgodnych z normą literacką języka czeskiego oraz dźwięcznych realizacji [ $\widehat{\mathrm{dz}}$ ]. Wyodrębniono 466 takich wymówień. Realizacje takie odnotowaliśmy zarówno u mówców pochodzących z Moraw, Śląska (11,5\%), jak i tych pochodzących z Czech właściwych (około 7\%). Najwięcej przykładów dotyczyło realizacji dźwięcznej wygłosowego $c[z]$ przed poszczególnymi sonantami nagłosowymi, np. vỉbec nic [vubez jits], nic moc [nIz mots], tisíc metrů [cIsi:z metru:], moc rád když [moz rá dI $\int$ ], nejvíc rozbité [nejvi:z rozbite:], konec rybničku [konez ribni:T $\int \mathrm{ku}$ ], nakonec méla [nakonez mpela]. W analizowanym materiale korpusowym odnotowano także bezdźwięczną realizację $c[\mathrm{~s}]$ przed niektórymi nagłosowymi sonantami, np. vỉbec nic [vu:bes nits], nic moc [nis mots], nic měnit [nis mjenıt], válec normálně [va:les norma:lje].

Wyniki przeprowadzonej analizy wskazują na wyraźną różnicę w stosunku do normy literackiej języka czeskiego. Pozwalają, tak jak w poprzedniej analizie, zakładać zróżnicowanie regionalne.

\section{Wnioski}

Sposób realizacji wygłosowego obstruentu na granicy międzywyrazowej określa konkretna reguła. Jak zauważyła Anna Korytowska dzieje się tak w większości języków słowiańskich a zmiany nacechowania pod względem dźwięczności nie mają charakteru fonetycznego, lecz regulowane są na poziomie głębszym. Użytkownicy języka stosują daną regułę bezwyjątkowo, na zasadzie ogólnie przyjętej konwencji, a jeśli w tych językach pojawiają się inne realizacje, naruszające reguły sandhi, to mają one związek z kontekstem sonantycznym albo dotyczą bardzo krótkich wypowiedzi (Korytowska 2012, s. 24-25).

Przeprowadzone przez nas badania wykazują, że w języku czeskim dochodzi do częstych odstępstw od istniejącej normy literackiej. Obok bezdźwięcznej realizacji obstruentów w wygłosie pierwszego wyrazu przed nagłosowym sonantem na granicy międzywyrazowej rejestruje się wymówienia z udźwięczniającą spółgłoską. Wahania wymowy dotyczą realizacji obstruentów dźwięcznych i bezdźwięcznych przed nagłosem sonantycznym. Odstępstwo od normy jest bardzo wysokie zwłaszcza w realizacji wygłosowego $t$ przed nagłosowym sonantem $l$. Rozdźwięk pomiędzy standardem języka czeskiego a regionalnymi odmianami języka czeskiego, który można zaobserwować przede wszystkim na płaszczyźnie morfologicznej, znajduje odbicie również w płaszczyźnie dźwiękowej języka. Zestawienie przykładów wyekscerpowanych z czeskiego korpusu języka mówionego pokazuje, że wymówienia z udźwięczniającą spółgłoską mają swoje pochodzenie w dialektach Morawskich. Wpływ na dużą liczbę wariantów wymowy odchodzącej od standardu ma również niedokładna wymowa, której przyczyny mogą tkwić, jak zwróciła uwagę Zdena Palková, w „sociokulturním zázemí mluvené komunikace s obecným trendem podporujícím neformálnost všeho druhu" (Palková 2007, s. 462). 


\section{Literatura}

B alowska G., 2006, Problematyka czeszczyzny potocznej nieliterackiej (tzw. obecná čeština) na tamach czasopisma »Naše řeč» w latach dziewięćdziesiatych, „Bohemistyka” 2006, nr 1, s. 25-46.

B o g o c z o v á I., 2012, Textová opora ke studiu mluveného českého jazyka a dialektologie, Ostrava.

C v rč e k V., Kovářík ová D., 2011, Možnosti a meze korpusové lingvistiky, „Naše řeč” 94, č. 3, s. 113-133.

Č e r má k F., 1995, Jazykový korpus: Prostředek a zdroj poznání, „Slovo a slovesnost" 56, s. 119-140.

H ál a B., 1967, Výslovnost spisovné češtiny I, Praha.

H ů r k o vá J., 1995, Česká výslovnostní norma, Praha.

Kopřivová M., Komrsková Z., Lukeš D., Poukarová P., Šk kar p o vá M., 2017, ORTOFON: Korpus neformálni mluvené čestiny s viceúrovňovým přepisem. Ústav Českého národního korpusu FF UK, Praha. Online: http://www.korpus.cz.

K o ry to w s k a A., 2012, Sandhi w standardzie języka macedońskiego, Toruń.

K r čm o vá M., 2008, Úvod do fonetiky a fonologie pro bohemisty, Ostrava.

P a l k o vá Z., 2007, Zvuková stavba češtiny v pohledu současného výzkumu, [w:] Komparacja współczesnych języków stowiańskich 2. Fonetyka. Fonologia, Opole, s. 461-478.

P a 1 k o vá Z., 2013, Sandhiové modifikace v současné čěstině, [w:] Sandhi w językach stowiańskich, red. A. Cychnerska, Toruń, s. 53-84.

P a 1 k o vá Z., 1994, Fonetika a fonologie češtiny, Praha.

P i a $\mathrm{k}$ a W., 2000, Gramatyka konfrontatywna języków stowiańskich z komentarzem historycznym, [w:] Gramatyka konfrontatywna języków słowiańskich t. I, red. W. Pianka, E. Tokarz, Katowice.

S a w i c k a I., 2007, Sandhi. Upodobnienia pod względem dźwięczności, [w:] Komparacja wspótczesnych języków stowiańskich 2. Fonetyka. Fonologia, red. I. Sawicka, Opole, s. 175-180.

S a w i c k a I., 2013, Wstęp [w:] Sandhi w językach stowiańskich, red. A. Cychnerska, Toruń, s. 7-46. 